\title{
FISH COMPOSITION AND DIVERSITY IN PERAK, GALAS AND KELANTAN RIVERS (MALAYSIA) AFTER THE MAJOR FLOOD OF 2014
}

\author{
Amonodin MOHAMAD RADHI *, Hashim ROHASLINEY * and Hazrin ZARUL ** \\ * University Putra Malaysia, Faculty of Environmental Studies, Serdang, Selangor, Malaysia, \\ MY-43400 UPM, radhi_aminuddin@yahoo.com, rohasliney@upm.edu.my \\ ** University Sains Malaysia, School of Biology, Minden, Penang, Malaysia, MY-43400, zarul@usm.my
}

DOI: 10.1515/trser-2017-0020

KEYWORDS: fish diversity, diversity index, Kelantan, Galas and Perak rivers.

\section{ABSTRACT}

Fish from three major rivers, namely the Kelantan River (KR) and the Galas River (GR) in Kelantan, and the Perak River (PR) in Perak, Malaysia, were caught using gill nets with different mesh sizes, cast nets, and the electroshock method. There were 14 fishes representing five families and five fish species were collected from the Kelantan systems in February 2015. While the Galas system holds more fish, 48 individual fishes comprising of four families and 10 fish species were found there. A total of 213 fish specimens representing 10 families and 22 species were captured in PR in May 2015. For diversity index, PR had the highest value due to the catchment area and the environmental condition: Shannon-Weiner index (H') (2.54), Species Evenness (J') (0.73) and Simpson's Dominance (D') (8.93), compared to GR (H') (2.09) (J') (0.603) (D') (6.52) and KR (H') (1.62) (J') (0.47) (D') (5.62).

RESUME: Composition et diversité piscicole dans les rivières de Perak, Galas et Kelantan à la suite des inondations majeures de 2014.

Les poissons des trois rivières importantes notamment la rivière de Kelantan (KR) et la rivière de Galas (GR) dans l'état de Kelantan, et la rivière de Perak (PR) dans l'état de Perak, Malaisie, ont été capturés avec des filets maillants de différentes dimensions, des filets à lancer et par la méthode d'électronarcose. Dans le système de Kelantan, 14 poissons ont été captures en février 2015, représentant cinq familles et cinq espèces. Le bassin de Galas a été plus riche avec 48 individus de quatre familles et 10 espèces de poissons. En PR, en mai 2015 ont été captures un total de 213 spécimens représentant 10 familles et 22 espèces. Concernant l'indice de diversité, PR a la valeur la plus importante due à la configuration du bassin et due aux conditions d'environnement: Indice Shannon-Weiner $\left(\mathrm{H}^{\prime}\right)(2,54)$, distribution $\left(\mathrm{J}^{\prime}\right)(0,73)$ et indice de dominance de Simpson (D') $(8,93)$, comparé avec GR (H’) $(2,09)$ (J') $(0,603)$ (D') $(6,52)$ et $\mathrm{KR}\left(\mathrm{H}^{\prime}\right)(1,62)\left(\mathrm{J}^{\prime}\right)(0,47)$ (D’) $(5,62)$.

REZUMAT: Speciile de pești și distribuția lor în râurile Perak, Galas și Kelantan după inundațiile majore din 2014.

În trei râuri mari, și anume Kelantan (KR) și Galas (GR) în statul Kelantan, și Perak (PR) în statul Perak, din Malaezia, au fost capturați pești utilizând plase de dimensiuni diferite ale ochiurilor, năvoade și prin metoda electronarcozei. În staţiile de pe Kelantan, în februarie 2015 au fost capturați 14 indivizi aparținând la cinci specii și cinci familii, pe când bazinul hidrografic Galas a prezentat o mai mare abundență, fiind capturați 48 de indivizi din zece specii și patru familii de pești. În total în PR au fost capturaţi 213 indivizi aparținând la 10 familii și 22 specii, în mai 2015. În ceea ce privește indicele de distribuție, PR a avut cea mai mare valoare datorită condiților de mediu și conformației bazinului hidrografic: indicele Shannon-Weiner (H') $(2,54)$, distribuția (J') $(0,73)$ și indicele de dominanță Simpson (D') $(8,93)$, față de GR (H') $(2,09)$ (J') $(0,603)$ (D') $(6,52)$ și KR (H') $(1,62)\left(J^{\prime}\right)(0,47)$ (D') $(5,62)$. 


\section{INTRODUCTION}

Rivers support a significant proportion of aquatic biodiversity including fish (Briones et al., 2004; Clausen and York, 2008; Bănăduc et al., 2011). Species’ richness within some tropical systems surpasses that of marine ecosystems, including coral reefs (Giller and Malmqvist, 2002; Rohasliney and Jackson, 2009). Additionally, associated semiaquatic/terrestrial habitats, such as seasonally-flooded forests, are an integral part of river ecosystems, and sustaining the water resources is a pre-requisite for their viability. Biologists have identified about 1.7 million species, the majority of which are insects followed by others including freshwater fishes. Worldwide, freshwater fishes are the most diverse of all vertebrate groups, but are also the most highly threatened (Mcdowall and Taylor, 2000). Chong et al. (2010) reported that a total of 1,951 species of freshwater and marine fish belonging to 704 genera, and 186 families have been recorded in Malaysia. In Peninsular Malaysia alone, about 278 native species were recorded. Thirty two fish species are currently categorized as highly threatened species (Chong et al., 2010). Cyprinidae (150 species) are the most dominant in most Malaysian aquatic ecosystems (Chong et al., 2010). To date, more than 35 freshwater species have been recorded in Kelantan (Department of Fisheries, 2005; Mohd Rezza and Rohasliney, 2009; Rohasliney et al., 2009; Ambak and Mohd Zaidi, 2010). However, previous studies have shown that there has been a substantial decline in fish densities during the last two decades, particularly affecting species such as Barbonymus schwanenfeldii, Hampala macrolepidota, Hysibarbus cf. pierrei, Poropuntius sp. undet., Scleropages formosus, and Tor spp. (Kvernevik, 1997). Ambak and Mohd Zaidi (2010) also reported seven species found in Kelantan River system, namely Ompok bimaculatus, Oxygaster anomalura, Neolissochilus hexagonolepis, Labiobarbus sumatranus, Hemibagrus nemurus, Osphronemus goramy, Acrossocheilus deuratus, are now considered to be rare species.

Most local people living along the Perak, Galas, and Kelantan rivers are part-time fishermen, especially those who live along the upper reaches of these rivers. This group of fishermen usually have other important sources of income such as agriculture, urban labour or transport, and many more with which they alternate their fishing activities. These fishermen are called subsistence fishermen, whereby they fish to supplement the family diet during slack periods in their daily schedule or seasonal calendar. Rarely do we see full-time fishermen (also known as food fishermen) in these rivers, and they comprise only 5-6\% of the total population (Fatin Athirah, 2015). There are also recreational fishermen who do not depend directly on the fishery for employment, instead treating fishing as a temporary pastime. In recreational fishing, once the fish is captured, it is returned to the water for the enjoyment of others. However, there is evidence that fish caught by recreational fishermen are sometimes taken home for food (Fatin Athirah, 2015). Living near the river is an advantage for fishermen. For food fishermen, the resources are readily available for them to fish daily. Fish are high in protein and minerals such as calcium and selenium. Fish are eaten whole or in fillets and sometimes fish is preserved as "ikan pekasam" or "ikan kering".

Floods are the most significant natural hazard in Malaysia in terms of population affected, frequency, area extent, flood duration, and socio-economic damage (Che Su et al., 2014). Normal floods are expected and generally welcomed in Malaysia as they provide rich soil, water, and a means of transport. The floods are directly caused by the weather in Malaysia, which is characterized by two monsoon regimes, i.e. the Southwest monsoon (May to September) and the Northeast monsoon (November to March). The Northeast monsoon is the major rainy season in the country. During flooding season, there is little fishing activity on most areas of the river as fishes are dispersed over the floodplain. If the river is flooding at an unexpected scale and with excessive frequency, the flood waters cause damage to life, 
livelihoods, and the environment. Fishing during heavy flooding is also rather risky. For example, in the year of 2014, the flooding in areas surrounding Perak, Galas and Kelantan rivers was disastrous. Thousands of people became homeless as their homes were washed away by aggressive currents, crops in the fields were destroyed, and infrastructure such as schools, hospitals, and markets were severely damaged. The three worst affected areas were Kuala Krai, Tanah Merah, and Gua Musang. Other than those districts, Kota Bharu (the state capital of Kelantan State) also was paralyzed for several days as the water level increased tremendously, almost submerging the entire town. The same tragic conditions could also be seen along Perak River, Perak, although the numbers of victims were fewer than in Kelantan. As the rising waters from Perak River and its tributaries inundated four areas statewide, many devastating tragedies followed suit and houses quickly became engulfed. Kampung Gajah, Lenggong, Kerian, Bota, Parit, Kuala Kangsar, and Sungai Siput were among the areas affected. The people who were most affected by the flood disaster were those living on the floodplain, especially the food and subsistence fishermen. They lost their fishing equipment, some of which was expensive. However, regardless of its monetary value, much equipment was lost or damaged and many months were spent repairing the damaged equipment.

Although floods inflict certain catastrophes on human beings, they play important ecological roles for other biotic components of a river. The biology and ecology of fish in large rivers are strongly linked to the annual hydrological regime in the main channel and the regular flooding of the associated floodplains (Welcomme, 1985a). A general pattern for reproductive migrations in floodplain rivers is an upstream spawning movement followed by a downstream dispersion of eggs, larvae, and spent adults into floodplain habitats (Carolsfeld et al., 2003; Borowsky, 2008).

The factors that influence the impact of floods on lotic fish communities include flood magnitude, timing, and frequency of disturbance (Kano et al., 2011; George et al., 2015). These factors determine flood strength and direction of abiotic and biotic responses. Responses of aquatic organisms to floods are also governed by the degree of environmental adaptation (Bischoff and Wolter, 2001). Living aquatic organisms can be severely affected by both abnormally high and low discharges. High discharges, for example, can wash away adult and juvenile fish (Welcomme and Halls, 2003). According to Baran (2006), diversity in catches is higher at lower discharge levels (between 2,000 and 8,000 cumecs) and decreases progressively as discharge increases. The movements of migratory movements are more diverse; they can be long, short, or at times absent; they can be upriver, downriver, or lateral into tributaries and the diversity of movements varies within and among species depending on water level (Makrakis et al., 2012).

Therefore, this study aimed to determine the composition and diversity of fishes after the major floods that occurred in 2014.

\section{MATERIAL AND METHODS Site description}

Perak River, Perak and its creek, Rui River, are freshwater or oligohaline. Perak River is dammed for hydro electrical purposes. There are four dams allocated along Perak River: Kenering Dam, Bersia Dam, Temenggor Dam and Chenderoh Dam. Rui River is located at Kenering Reservoir, which is between Bersia and Kenering dams (Fig. 1). The study was conducted in Rui River (Fig. 1), which is the only tributary in Kenering system that flows directly into the main stream of Perak River. The river is located at the latitude and longitude coordinates of N $5^{\circ} 27^{\prime} 27.1^{\prime \prime}, \mathrm{E} 101^{\circ} 10^{\prime} 38.8^{\prime \prime}$. Several villages and small industries are located 
along Rui River. The upper stream of Rui River, Kampung Pong, is inhabited by several indigenous people and Siamese people. A small dam, named Pong Dam, was built there for power supply to transport tin mined in Klian Intan to the processing area at Gerik previously (Gerik District Council, 2011). The physical condition of the environment is still in a good state. Significant riparian zones are found there with numerous rubber plantations. Tin mining activity is still operational at the upper stream region. While downstream of Rui River, common Malay villages can be found such as Kampung Pahit Luar, Kampung Alai, Kampung Plang and Kampung Kerunai. Near the confluence of Rui River, Kuala Rui is commonly inhabited by Chinese. Plantations and housing are more prevalent in the downstream area, with acceptable riparian zones. However, some areas, such as Dataran Loma, have been altered permanently for fishing activity. Fishing is secondary work and a recreational activity for villagers. This activity becomes more active during wet season as larger numbers of fish spawn in the upper stream of Rui River. The wet season occurs in Gerik District from March to May and in September and October, while dry season is during January and February and from June to August (Zarul, 2013). Most studies conducted in the Perak River have focused on Temengor Reservoir, the most upstream reservoir in the series. More recent studies include analyses of physico-chemical or water quality and fish assemblages (Hashim et al., 2004; Hashim, 2006; Khalik and Abdullah, 2012) in Temengor Reservoir and its water catchment areas. Only Zarul (2013) reported that water quality in Kenering system (temperature $29.0^{\circ} \mathrm{C}$, conductivity $48 \mu \mathrm{s} / \mathrm{cm}$, total dissolved solid $27 \mathrm{mg} / \mathrm{l}$ ) was Class I during his study from July 2009 to December 2010.

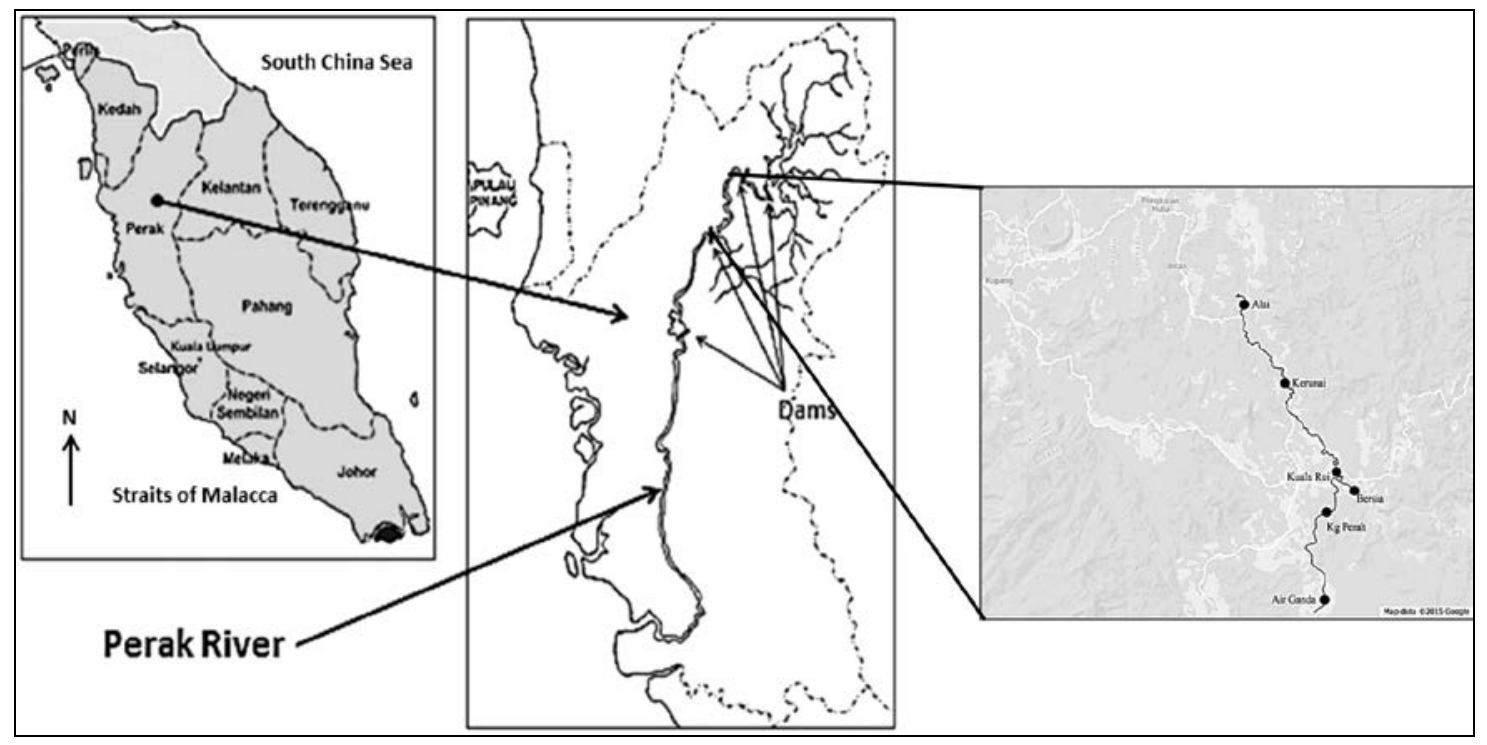

Figure 1: Location of Perak State showing the Perak River, the four dams (along the Perak

River) and sampling points (map of Peninsula Malaysia was adapted and modified from http://www.malaysiavacationguide.com/malaysiamap.html) (accessed on January 18th, 2016).

The Kelantan River basin is located in the north eastern part of Peninsular Malaysia; the maximum length and breadth of the catchment are $150 \mathrm{~km}$ and $140 \mathrm{~km}$ respectively. The Kelantan River is about $248 \mathrm{~km}$ long and drains an area of 13,100 km², occupying more than $85 \%$ of the State of Kelantan. The Kelantan River is a unique river in Southeast Asia since it is the only river known to flow northwards (Fig. 2). The main river from source to river mouth 
has four tributaries; originating from the Betis River (the first $30 \mathrm{~km}$ from the source), then the Nenggiri River, followed by the Galas River, before meeting the Lebir River to form the Kelantan River. The Kelantan River regularly overspills its bank from November to February during the northeast monsoon season. The river flows past four important towns: Kuala Krai, Pasir Mas, Tumpat, and Kota Bharu, the latter being the state capital, which lies near the mouth of the river. Overall, the Kelantan River was classified as a clean river after the Water Quality Index (WQI) for the river was found to be above 80. Over a five-year period, the WQI value for the Kelantan River increased from 84 (year 2005) to 85 (years 2007 to 2009). The WQI value was 82 in both 2011 and 2012 (Department of Environment, 2011, 2012). The Kelantan River has been used heavily by the local people for domestic use, transportation, agriculture, plantation irrigation, small-scale fishing and sand mining (Fig. 1). The Kelantan River's water has been turbid since the early 1990s due to high levels of suspended solids and siltation. This has been caused by logging in the upstream areas (Lojing Highlands) (Department of Environment, 2009; Ambak and Mohd Zaidi, 2010) and sand mining (Tan and Rohasliney, 2013).

The Galas River is the main tributary of the Kelantan River. The length of the river is $178 \mathrm{~km}$ and its catchment area is about $7,770 \mathrm{~km}^{2}$ with main geological features of shale, mudstone, and limestone (Fig. 2). The Galas River flows northward passing through Ulu Galas Forest Reserve to villages and towns, such as Ulu Pulai, Limau Kasturi, Dabong, Gua Musang and Kuala Krai, before joining other rivers (i.e., the Nenggiri and Pergau rivers) to form the Kelantan River. Land use along the Galas River was observed through groundtruthing. Out of three rivers sampled and monitored, the Galas River tended to reflect the most natural state, especially the upstream part of the river. However, downstream, oil palm and rubber plantations can be found nearby. In addition, the Galas River has been used heavily by local people for domestic purposes, transportation, agriculture, plantation irrigation, and small scale fishing.

\section{Data collection}

Fish were collected using experimental gill nets along the Perak River (Bersia to Kenering Reservoir), the Galas River, and the Kelantan River. The gill nets were set at each sampling site for 24 hours. More than 20 sites in the main rivers were sampled. Fish were also caught using gill nets with separate mesh sizes of two, three, and four inches, in order to enhance the fish catch. Each fish net was inspected every day for five days from morning until afternoon. The fish nets (measuring $30 \mathrm{~m}$ length, $1.5 \mathrm{~m}$ depth) were set up along stretches of river that covered most river pools. In the case of the Perak River, a cast net and a portable backpack electrofishing unit, Model LR-24 (400 V; 60 Hz) (Smith-Root Inc., Washington, USA), were also used, depending on the suitability of sampling locations. All captured fish were labelled accordingly and placed in an ice-chest. Each fish was then measured for its total length $(\mathrm{cm})$ and weight $(\mathrm{g})$, and were carefully preserved in $10 \%$ ethanol for further studies. Voucher specimens were retained for laboratory verification. These voucher specimens were preserved, labelled, and stored in the Faculty of Environmental Studies, UPM. Fish data from the Kelantan and Galas rivers were collected from 14 March 2015 to 18 March 2015, whereas fish sampling at the Perak River was conducted from 22 May 2015 to 28 May 2015. 


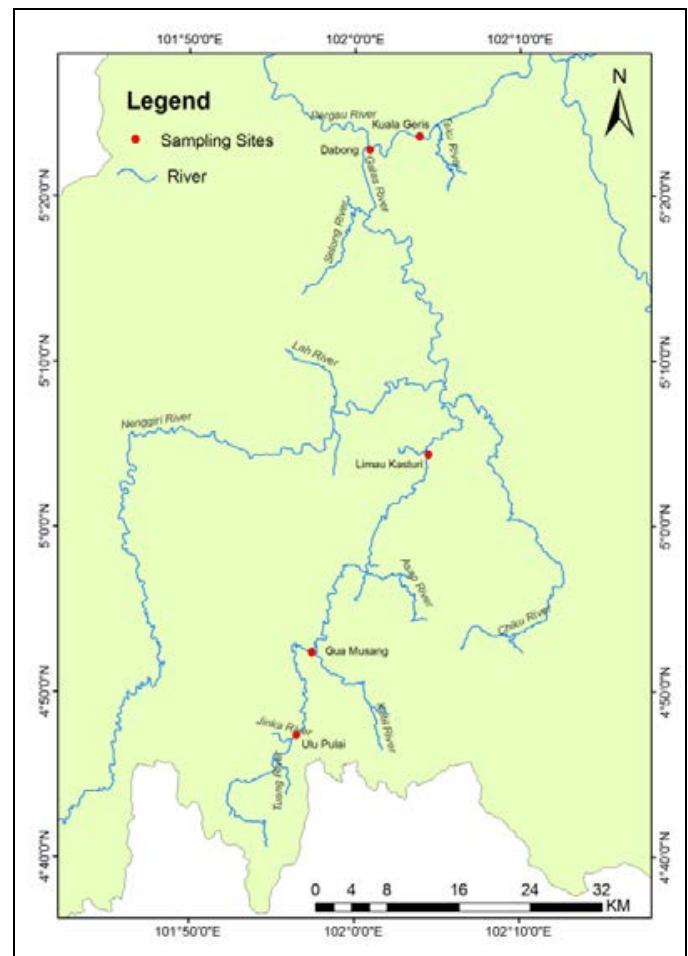

a.

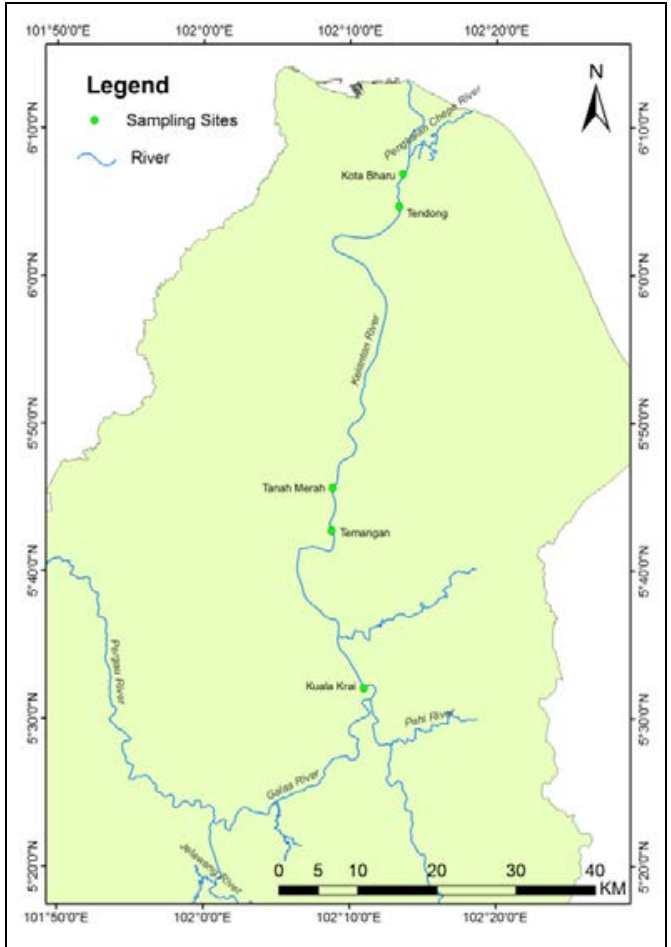

b.

Figure 2: Maps of Kelantan showing two river basins (from south to north: (a) Galas River basin and (b) Kelantan River basin), showing sampling stations along the two rivers. 


\section{RESULTS AND DISCUSSION}

Overall, 31 fish species representing 14 families (Tab. 1) were caught throughout the study. Two families of fish were found throughout the three systems; the Cyprinidae with 19 species and the Bagridae with three species. Perak River had the highest number of fish caught with 10 families and 22 species (Tab. 1). From 213 individuals, the Clupeichthys perakensis made up $27.2 \%$ with a total length of $3-4.7 \mathrm{~cm}$. This may have been partly due to the equipment used, namely, a modified scoop net and partly due to behaviour of this species (swimming near the banks of the river). The accumulation of Clupeichthys perakensis at the edge of the Perak River made this species an easy fishing target. In contrast with the findings of Zarul (2013), using the same gear (gill nets), three new species were found: Channa marulioides, Leptobarbus hoevenii and Osphronemus goramy. All three species were caught at Air Ganda, a lower stream of Perak River, which has a bigger catchment area compared to that of the Rui River. According to Chew and Zulkafli (2007), Leptobarbus hoeveni and the Osphroremus gouramy are considered to be rare species that only inhabit undisturbed river conditions.

Different groups of fish were caught between headwater (Rui River) and downstream (Rui and Perak rivers). Zarul (2013) recorded a total of 21 species that were not caught during this study; these species were: Hemibargus nemurus, Hemibargus planiceps, Clarias batrachus, Cyclocheilichthys armatus, Labiobarbus fasciatus, Labiobarbus festivus, Labiobarbus leptocheilus, Labiobarbus lineatus, Osteochilus melanopleurus, Osteochilus microchepalus, Oxygaster anomalura, Poropuntius deauratus, Rasbora sumatrana, Thynnichthys thynnoides, Tor spp., Oxyeleotris marmorata, Mastacembelus erythrotaenia, Chitala chitala, Chitala lopis, Trichogaster trichopterus and Pseudolais micronemus. The difference in the timing of our study and Zarul's study may explain this outcome. Zarul (2013) took samples from 2009 to 2010 (17 months), while our study was conducted only during May 2015 (one month). However, in the Bintang Hijau area, five new species from various families were found upstream of the river, adding up the checklist made by Zarul (2013) which was composed of Amblyceps foratum, Betta pugnax, Monopterus javanensis, Devario regina, Barbodes binotatus and the Neolissochilus soroides. The electro-shocker gear that was used in this study may explain the condition. The pristine condition of the river upstream, as a result of minimal human engagement, has made the river habitable for such sensitive species. One non-native species was also found in the Perak River (i.e. Oreochromis niloticus) that could have escaped from a pen culture at the Temenggor Reservoir (upper reservoir) during flooding. Although only a small number of this non-native species was found, if the current situation is not studied and controlled well, predation by these non-native invasive species may be the most likely outcome (Clavero and Hermoso, 2011). 
Table 1: Fish species captured from the Perak River (PR), the Galas River (GR), and the Kelantan River (KR) in February, March, and May of 2015 (after major flood occurred in December 2014).

\begin{tabular}{|c|c|c|c|c|}
\hline Family & Species & PR & GR & KR \\
\hline Amblycipitidae & Amblyceps foratum (Ng and Kottelat, 2000) & + & - & - \\
\hline Ariidae & Arius maculatus (Thunberg, 1792) & - & - & + \\
\hline \multirow[t]{2}{*}{ Bagridae } & Hemibagrus capitulum (Popta, 1960) & - & + & - \\
\hline & Mystus castaneus (Ng, 2002) & + & - & + \\
\hline \multirow[t]{2}{*}{ Channidae } & Channa marulioides (Bleeker, 1851) & + & - & - \\
\hline & Channa micropeltes (Cuvier, 1831) & + & - & - \\
\hline Cichlidae & Oreochromis niloticus (Linnaeus, 1758) & + & - & - \\
\hline Clariidae & Clarias gariepinus (Burchell, 1822) & - & - & + \\
\hline Clupeidae & Clupeichthys perakensis (Herre, 1936) & + & - & - \\
\hline \multirow[t]{14}{*}{ Cyprinidae } & Barbonymus gonionotus (Bleeker, 1849) & + & - & - \\
\hline & Barbonymus schwanenfeldii (Bleeker, 1854) & + & + & + \\
\hline & Cyclocheilichthys apogon (Valanciannes, 1842) & + & + & - \\
\hline & Devario regina (Fowler, 1934) & + & - & - \\
\hline & Hampala macrolepidota (Kuhl and Van Hasselt, 1823) & + & + & - \\
\hline & Leptobarbus hoevenii (Bleeker, 1851) & + & - & - \\
\hline & Mystacoleucus obtusirostris (Valenciennes, 1842) & - & + & - \\
\hline & Neolissochilus soroides (Duncker, 1904) & + & - & - \\
\hline & Osteochilus enneaporos (Bleeker, 1852) & - & + & - \\
\hline & Osteochilus vittatus (Valenciennes, 1842) & + & + & - \\
\hline & Oxygaster anomalura (Hasselt, 1823) & - & + & - \\
\hline & Puntioplites bulu (Bleeker, 1851) & + & - & - \\
\hline & Barbodes binotatus (Valenciennes, 1842) & + & - & - \\
\hline & Rasbora tornieri (Ahl, 1922) & + & - & - \\
\hline Mastacembelidae & Mastacembelus erythrotaenia (Bleeker, 1850) & - & + & - \\
\hline Nandidae & Pristolepis fasciata (Bleeker, 1851) & + & - & - \\
\hline \multirow[t]{2}{*}{ Notopteridae } & Chitala lopis (Bleeker, 1851) & - & - & + \\
\hline & Notopterus notopterus (Pallas, 1769) & + & - & - \\
\hline \multirow[t]{2}{*}{ Osphronemidae } & Betta pugnax (Cantor, 1849) & + & - & - \\
\hline & Osphronemus goramy (Lacepède, 1801) & + & - & - \\
\hline Pangasiidae & Pseudolais micronemus (Bleeker, 1846) & - & + & - \\
\hline \multirow[t]{3}{*}{ Synbranchidae } & Monopterus javanensis (Lacepède, 1800) & + & - & - \\
\hline & Number of families collected & 10 & 4 & 5 \\
\hline & Number of species collected & 22 & 10 & 5 \\
\hline
\end{tabular}


A total of 245 individual fish were collected from the Kelantan River, comprising of five families and five fish species (Tab. 1). Barbonymus schwanenfeldii was the most abundant species $(42.9 \%$ of total catch) and had a total length ranging between 13 and $27.8 \mathrm{~cm}$. Evidently, Mystus castaneus was only caught during this sampling period (35.7\% of the total average catch with a total length of 16-25 cm) and was not observed between 2010 and 2012 (Rohasliney et al., 2015). Chitala lopis, the Clarias gariepinus, and the Arius maculatus were almost equally abundant throughout the river (7.1\%). There was a higher number of catches at the downstream areas (10 individuals) compared to the middle reaches of the river (four individuals). This may have been caused by the change in habitat, as a result of flooding, such as significant bank erosion, enormous bed-load transfer, change in velocity of current and also depth of pool. All of these factors most probably affected the spawning, feeding, and shelter areas of the fishes in that area. Compared to the Galas River and the Perak River, the Kelantan River has undergone enormous human intervention such as sand mining and logging activities, which have caused benthic habitat destruction and water turbidity (Tan and Rohasliney, 2013). The Kelantan River is now under increasing pressure from sand mining activities. There are about 128 sand mining companies operating in the river from Kuala Krai down to Kelantan's estuary (Ambak and Mohd Zaidi, 2010). Hence, the Kelantan River has started to become very turbid due to a high suspended solids content and siltation. The Kelantan River upstream is threatened by logging activities which correspondingly lead to very turbid water downstream (Tan and Rohasliney, 2013). In some parts of the river, tremendous stress from drought and erosion of the stream bank was observed. Rapid rural development from Tanah Merah to Kota Bharu has led to over-grazing, deforestation and erosion. The conversion of floodplains and riparian zones to agriculture and urban development (i.e., TESCO, a series of waterfront hotels and houses) has had detrimental effects on plants and animals in riverine wetlands. Discontinuity of the floodplain would affect the population of fish adversely. In addition to the general loss of production, changes in the composition of the fish fauna have occurred downstream of the Kelantan River. In some cases, a decline in the swamp-dwelling and herbivorous fishes was noted, and their predators have increased in abundance. Such a disproportionate number of predators cannot persist for any length of time and will eventually act to reduce the abundance of the stock as a whole (Noor Syuhadah and Rohasliney, 2011).

In the Galas River, a total of 48 fish individuals were collected, comprising of four families and 10 fish species. The only species that was high in abundance in the Galas River was the Cyclocheilicthys apogon (41.7\% of the total average catch with a total length of 15.8-28.1 cm). The high abundance of Temperas in the Galas River may be related to its feeding habit, which is omnivore-detritivore, and the Galas River is known for its rich and varied food sources. Kah-Wai and Ali (2001) found that this species was the second most abundant species in the Chenderoh Reservoir where it made up $22 \%$ of the total catch. This species was followed by Barbonymus schwanenfeldii, Hemibagrus capitulum, and Mystacoleucus obtusirostris $(14.6 \%, 12.5 \%, 8.3 \%$ of the total catch with a total length of 16.8-28.1, 22.5-32.6, and 17.2-18.5 cm, respectively). There were six fish species caught in this study that were not observed during sampling between 2008 and 2010: Hemibagrus capitulum, Mystacoleucus obtusirostris, Osteochilus enneaporus, Osteochilus vittatus, Mastacembelus erythrotaenia and Pseudolais micronemus (Rohasliney et al., 2015). 
In contrast to the Kelantan River, the Galas River is located in the Ulu Galas Forest Reserve where the river still has an intact forest and riparian zone so that it remains a good habitat and source of food for most fish species (Rohasliney, 2010). Although there has been a declining trend in the abundance of the Hampala microlepidota species (three individuals) (6.25\% average catch), Rohasliney et al. (2015) found more than 20 individual fish from 2008 to 2010. The declining trend may be related to destruction of spawning habitat and drifting of fry that are less capable of overcoming strong currents during the flood (Welcomme, 1985b; Reichard and Jurajda, 2004). In contrast, the Galas River downstream is subjected to anthropogenic influences and the fish communities observed are mostly dominated by nonnative species. It has been hypothesized that the numerically dominant non-native species are better adapted for altered water quality, habitat, and hydrological condition (Bennet and Moyle, 1996). However, interestingly, species richness is quite high at Dabong's sampling site which is considered to be downstream of the Galas River (Tab. 1) (Mohd Rezza and Rohasliney, 2009). This is partly because Dabong remains a remote area with minimal development. Furthermore, additional fish species from the Pergau River enter the Galas River when the two rivers meet just below the sampling point at Dabong site. The Galas River is categorized as a Class II river using the WQI chemical classification, which was developed by the Department of Environment (2006). Class II can be used for recreation with body contact and may contain sensitive aquatic species. As for domestic water supply, a Class II river may need conventional treatment.

The number of fish species in the Kelantan River was the lowest (Fig. 3a) compared to that found in the Galas and Perak rivers. This is because of a distinctive feature of the potamon area (wide and slow-moving river characteristics) especially at the middle and lower reaches of Kelantan River, characterised by higher in turbidity caused by active sand mining activities along Kelantan River. This action has also changed the natural habitat of the river, resulting in the deepening of the pool, loss of gravel on the riverbed, and the introduction of extensive mud and silt. All of these consequences affect the fish community directly in regard to their spawning, feeding, and protection areas. Species evenness (Fig. 3c) and Simpson's dominance (Fig. 3d) revealed that fish diversity for the Kelantan River sample was moderate at 0.47 and 5.62, respectively. On the other hand, concerning the Galas River, the high number of species shown in figure 3a, along with the unequal distribution of individuals among species, has resulted in lower species diversity, as revealed by the Shannon-Weiner index (2.09) (Fig. 3c) and Simpson's dominance (6.52) (Fig. 3d). The highest number of species out of all the rivers studied was observed in the Perak River (Fig. 3a). This is likely due to the nature of the reservoir river where plenty of allochthonous materials from lower order streams are brought together. The existing vegetation and trees are the source of these autochthonous materials. The Shannon-Weiner index at the Perak River also yielded the highest value of 2.54 (Fig. 3a) compared to Galas River (2.09) and the Kelantan River (1.62). The species diversity for the Perak River was the highest, as indicated by species evenness (0.73) (Fig. 3c) and Simpson's dominance (8.93) (Fig. 3d). This indicates that the species were log distributed normally, which means that certain species are more abundant than others. 

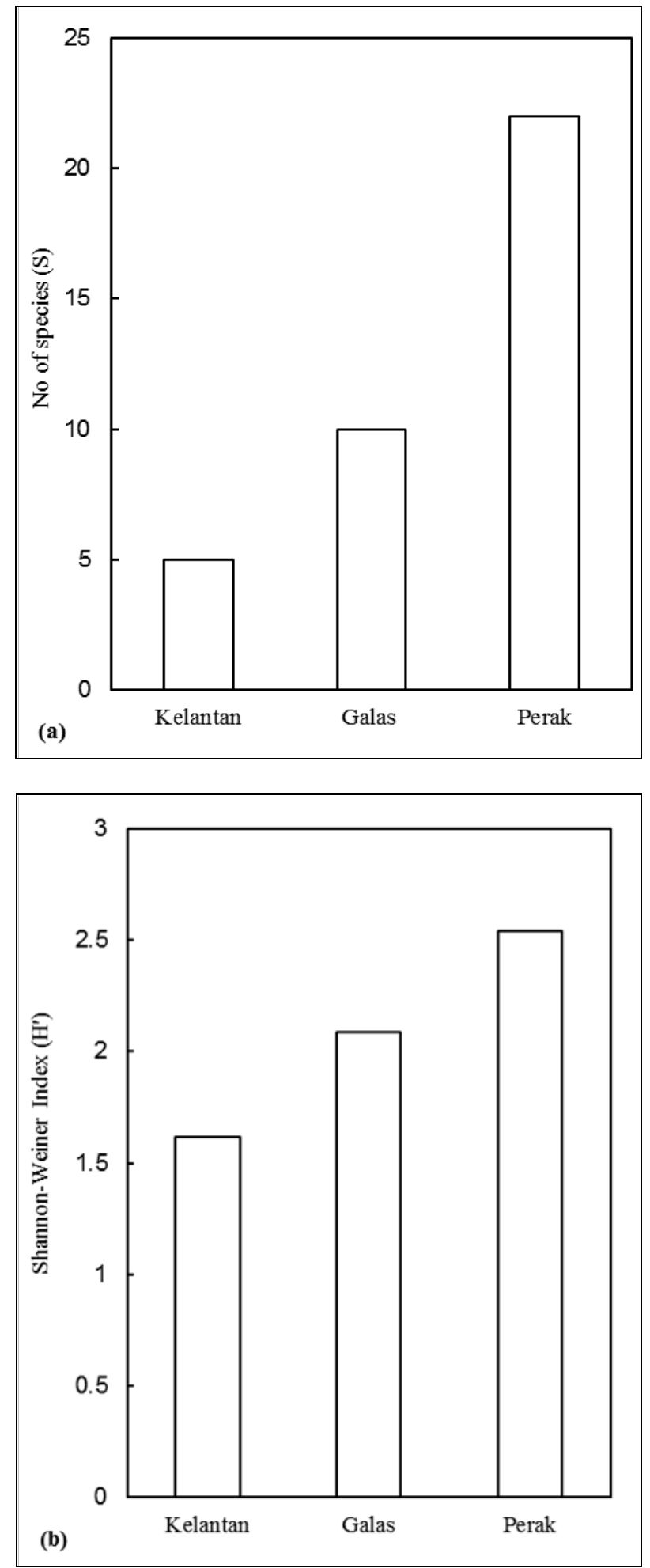

Figure 3a, b: Total number of species (a), Shannon-Weiner index (H’) (b) from samples collected at the KR, the GR, and the PR in February, March, and May of 2015. 

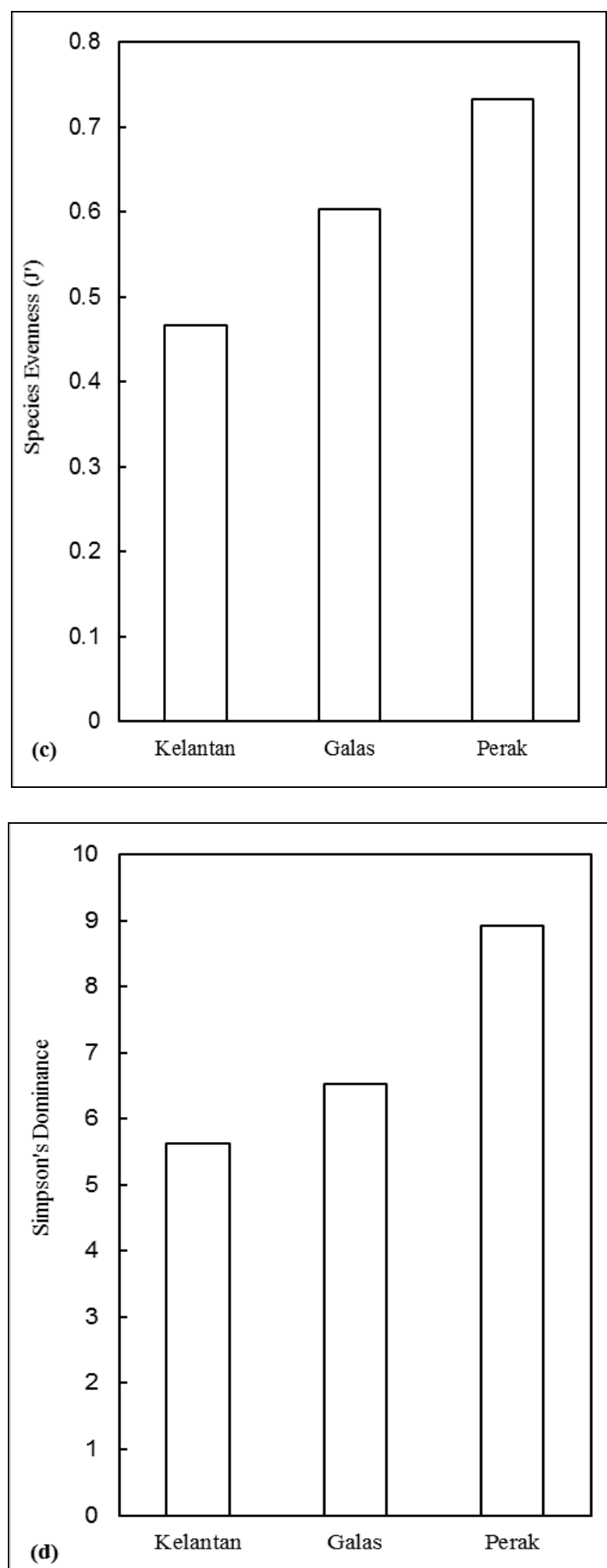

Figure 3c, d: Total Species evenness (J') (c) and Simpson's dominance (d) from samples collected at the KR, the GR, and the PR in February, March, and May of 2015. 


\section{CONCLUSIONS}

The richness of fish species at the Perak River indicates that the river is in good condition. Meanwhile, the low rate of production from fisheries production along the Kelantan and Galas rivers is at an alarming state. Human activities that cause habitat degradation and water pollution should be managed properly via appropriate action from relevant authorities. Requirements for sustaining biodiversity and fisheries in rivers are integrally linked through a mutual need for improved management of both habitats and their exploitation. 


\section{ACKNOWLEDGEMENTS}

We would like to send our appreciation to Azhilah Abdullah, Amirul Aizal Abdul Aziz, Nurul Fazlinda Mohd Fadzil and Basharudin for helping the team in the field and laboratory. Finally, we thank Carol Hutchinson for her English editing contribution in this manuscript. This study was sponsored by UPM Putra Grant GPM/2013/9422500 (University Putra Malaysia). 


\section{REFERENCES}

1. Ambak M. A. and Mohd Zaidi Z., 2010 - Freshwater fish diversity in Sungai Kelantan, Journal of Sustainability Science and Management, 5, 13-20.

2. Baran E., 2006 - Fish migration triggers in the Lower Mekong Basin and other tropical freshwater systems, MRC Technical Paper, 14, 55.

3. Bănăduc D., Oprean L. and Alexandru B., 2011 - Fish species of Community interest management issues in Natura 2000 Site Sighişoara-Târnava Mare (Transylvania. Romania), Crises after the crisis: inquieres from a national, European and Global perspective, II, 23-27.

4. Bennet W. A. and Moyle P. B., 1996 - Where have all the fishes gone? Interactive factors producing fish declines in the Sacramento-san Joaquin Estuary, in 75th Annual meeting of the Pacific Division/American Association for the Advancement of Science, San Francisco, California, 519-542.

5. Bischoff A. and Wolter C., 2001 - The flood of the century on the river Oder: Effects on the 0+ fish community and implications for floodplain restoration, Regulated Rivers-Research and Management, 17, 171-190.

6. Briones M., Dey M. M. and Ahmed M., 2004 - The future for fish in the food and livelihoods of the poor in Asia, WorldFish Center Quarterly, 27, 3-4, 48-50.

7. Carolsfeld J., Harvey B., Ross C. and Baer A., 2003 - Migratory fishes of South America: Biology, fisheries and conservation Status, in Fisheries and Conservation Status, Victoria, BC: World Fisheries Trust, 372.

8. Che Su M., Najib Ahmad M., Mohd Taib A., Nurul Aaina S. and Rahaman N. H., 2014 Relationship between social support, impression management and well-being among flood victims in Malaysia, Procedia - Social and Behavioral Sciences, 155, 197-202.

9. Chew P. C. and Zulkafli A. R., 2007 - Sperm cryopreservation of some freshwater fish species in Malaysia, in Igor Katkov (ed.), Current Frontiers in Cryopreservation, 269-292, in Tech China.

10. Chong V. C., Lee P. K. Y. and Lau C. M., 2010 - Diversity, extinction risk and conservation of Malaysian fishes, Journal of Fish Biology, 76, 2009-2066.

11. Clausen R. and York R., 2008 - Global biodiversity decline of marine and freshwater fish: A cross-national analysis of economic, demographic, and ecologic influences, Social Science Research, 37, 4, 1310-1320.

12. Clavero M. and Hermoso V., 2011 - Reservoirs promote the taxonomic homogenization of fish communities within river basins, Biodiversity and Conservation, 20, 41-57.

13. Council G. D., 2011 - Pong Dam. Retrieved November 10, 2015, from http://www.gerik.gov.my/empangan-pong;jsessionid=61424DEEBD323A8242DA7164CAFFC AE9

14. Department of Fisheries, 2005 - Annual Fisheries Statistics.

15. Department of Environment, 2006 - Annual report of Department of Environment, Kelantan 2006.

16. Department of Environment, 2009 - Malaysia Environmental Quality Report 2009.

17. Department of Environment, 2011 - Malaysia Environmental Quality Report 2011.

18. Department of Environment, 2012 - Malaysia Environmental Quality Report 2012.

19. Fatin Athirah M. A., 2015 - Recrational creel survey in Langat River, Universiti Putra Malaysia.

20. George S. D., Baldigo B. P., Smith A. J. and Robinson G. R., 2015 - Effects of extreme floods on trout populations and fish communities in a Catskill Mountain river, Freshwater Biology, 60, 2511-2522.

21. Giller P. and Malmqvist B., 2002 - The biology of streams and rivers. Biology of habitats, New York: Oxford University Press, 296.

22. Hashim Z. H., 2006 - Physico-chemical parameters and fish diversity in two disturbed low-order headwater streams in Temengor Reservoir, Perak, University Sains Malaysia, 182. 
23. Hashim Z. H., Shah A. S. R. M., Khoo K. H. and Ali A. B., 2004 - Biodiversity of natural fish resources in disturbed mountainous low-order river systems in Temenggor, in Proceedings of second Bangi world conference on environmental management: changing conditions, Universiti Kebangsaan Malaysia and Environmental Management Society, Kuala Lumpur, 194-205.

24. Kah-Wai K. and Ali A. B., 2001 - Chenderoh Reservoir, Malaysia: Fish community and artisanal fishery of a small mesotrophic tropical reservoir, in Reservoir and Culture-Based Fisheries: Biology and Management, Bangkok: Australian Centre for International Agricultural Research, 167-168

25. Kano Y., Ohnishi K., Tomida Y., Ikeda N., Iwawaki N., Miyagawa M. and Watanabe K., 2011 Fluctuation and variation in stream-fish assemblages after a catastrophic flood in the Miyagawa River, Japan, Environmental Biology of Fishes, 92, 447-460.

26. Khalik W. M. A. and Abdullah M. P., 2012 - Seasonal influence on water quality status of Temenggor, The Malaysian Journal of Analytical Sciences, 16, 163-171.

27. Kvernevik T., 1997 - Movement patterns of fishes in Malaysian rivers: effect of migration barriers on community structure, University of Oslo, 110.

28. Makrakis M. C., Miranda L. E., Makrakis S., Fontes Júnior H. M., Morlis W. G., Dias J. H. P. and Garcia J. O., 2012 - Diversity in migratory patterns among Neotropical fishes in a highly regulated river basin, Journal of Fish Biology, 81, 866-881.

29. Mcdowall R. and Taylor M., 2000 - Environmental indicators of habitat quality in a migratory freshwater fish fauna, Environmental Management, 25, 357-374.

30. Mohd Rezza P. A. and Rohasliney H., 2009 - Study of freshwater fish assemblages and its productivity at Galas River, Kelantan, in 2nd International Conference Proceeding: Ecology, Human Habitat and Environmental Changes, 167-174.

31. Noor Syuhadah S. and Rohasliney H., 2011 - A preliminary study on batik effluent in Kelantan State: A water quality perspective, in International Conference on Chemical, Biological and Environment Sciences (ICCEBS’2011) Bangkok Dec., 274-276.

32. Reichard M. and Jurajda P., 2004 - The effects of elevated river discharge on the downstream drift of young-of-the-year cyprinid fishes, Journal of Freshwater Ecology, 19, 465-471.

33. Rohasliney H., 2010 - Status of river fisheries in Kelantan, World Academy of Science, Engineering and Technology, 41, 801-805.

34. Rohasliney H. and Jackson D. C., 2009 - Fish assemblages in streams subject to anthropogenic disturbances along the Natchez Trace Parkway, Mississippi, USA, Tropical Life Sciences Research, 20, 29-47.

35. Rohasliney H., Mohd Rezza Petra A., Wan Mohd Amzar M. Z., Jusoh Amirah S. and Amir Shah Ruddin M. S., 2015 - Fish distribution and composition of Kelantan River systems, Kelantan, Malaysia, Applied Mechanics and Materials, 747, 294-297.

36. Rohasliney H., Siti Amirah J., Nurul Izzati A. S., Mohd Rezza P. A., Miti Fateema Yusliza M. Y. and Amir Shah Ruddin M. S., 2009 - Comparison of fish diversity in unpolluted and polluted river, Kelantan, in The 3rd Regional Conference on Natural Resources in Tropics, 476-791.

37. Tan P. Y. and Rohasliney H., 2013 - Status of water quality subject to sand mining in the Kelantan River, Kelantan, Tropical Life Sciences Research, 24, 19-34.

38. Welcomme R. L., 1985a - Ecology of flood plain River fisheries, Rome: Food and Agriculture Organization of the United Nations, 330.

39. Welcomme R. L., 1985b - River fisheries, Food and Agriculture Organization Fisheries Technical Paper, 262, 330.

40. Welcomme R. L. and Halls A., 2003 - Dependence of tropical river fisheries on flow, in Proceedings of the Second International Symposium on the Management of Large Rivers for Fisheries, Bangkok: FAO, 267-283.

41. Zarul H., 2013 - Limnological influence of dams placed in series along the Perak River, Malaysia, Mississippi State University, 108. 